\title{
Reseña Bibliográfica: de Ayala Martínez, C. (2016). El pontificado en la Edad Media. Madrid: Síntesis. 403 pp.
}

Palabras clave: Pontificado Medieval - Historia Política - Autoridad Papal - Libertas Ecclesiae

Keywords: Medieval Pontificate - Political History - Papal Authority - Libertas Ecclesiae

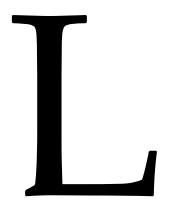

a obra aquí reseñada, escrita por Carlos de Ayala Martínez, doctor en historia medieval y catedrático de la Universidad Autónoma de Madrid, tiene como objetivo presentar una parte de la historia del pontificado, evidenciando panorámicamente su nacimiento y evolución a lo largo de un periodo que, convencionalmente, se ha denominado Edad Media. El autor es un académico de larga trayectoria y sus intereses lo han llevado a realizar una notable investigación centrada en los siglos XII y XIII castellanos (el reinado de Alfonso X de Castilla, las Órdenes militares hispánicas y los problemas relativos a la cruzada y guerra santa, así como las implicaciones de las mismas en la política).

El libro, publicado por la editorial Síntesis, forma parte de una nueva colección de manuales universitarios destinados a cubrir los vacíos de producción historiográfica en lengua española. Efectivamente, si bien existen trabajos similares en otros idiomas, el libro de Ayala no deja de ser doblemente novedoso por estar escrito en español y abarcar un amplio marco temporal, que él mismo define como una historia "milenaria". Este trabajo gira en torno a un eje argumental: la pretensión papal de insistir en que su autoridad -derivada de aquella concedida a san Pedro- proviene directamente de Cristo. La obra sigue la periodización realizada por el autor y se divide en cinco partes.

La primera parte abarca un periodo que se extiende entre los siglos IV y VII. En ella se estudian los antecedentes del pontificado medieval y los elementos que ayudaron a configurar la tradición petrina, sobre la cual los obispos de Roma forjaron paulatinamente una conciencia de superioridad honorifica frente a las demás comunidades cristianas. Para el autor, esta pretensión de autoridad, hizo que los papas se enfrentaran al poder imperial intentando emanciparse de este, puesto que, desde comienzos del siglo IV, la Iglesia formaba parte de su estructura. En este sentido, la crisis que afectó al imperio -sobre todo a la parte occidental- tras la muerte de Teodosio en el 397, es presentada como una coyuntura favorable para el pontificado, que le permitió que personajes destacados, como los papas León I, Gelasio I y Gregorio Magno, realizaran un gran aporte a la creación de la doctrina del primado apostólico para 
defender la preeminencia de la Sede romana, tanto en materias doctrinales y espirituales, como en asuntos de gobierno temporal frente a la autoridad de los emperadores bizantinos. De todas maneras, el autor explica que las injerencias de los poderes laicos no finalizaron, ya que a partir del 493 con la tutela ostrogoda y, posteriormente, desde la década de 530 bajo la denominada cautividad bizantina, la sede romana estuvo sujeta a intromisiones continuas por parte de reyes y emperadores en el gobierno de la Iglesia, situación de la cual no fue fácil desligarse.

En la segunda parte se analiza el periodo que se extiende desde la mitad del siglo VIII hasta mediados del siglo XI. Esta fase es presentada como una de las más difíciles por las cuales tuvo que atravesar el pontificado medieval. La necesidad de protección frente a la amenaza bizantina y lombarda llevó a los papas a establecer una aproximación estratégica y recíprocamente interesada con el reino de los francos. Gracias a esta colaboración se constituyó un principado territorial sujeto a la soberanía de la sede apostólica, conocido como los Estados Pontificios. Sin embargo, de Ayala plantea que este poder territorial quedó circunscripto al ducado de Roma, ya que, a raíz de la desintegración del imperio carolingio, estos territorios quedaron desamparados del protectorado franco, y fueron agobiados por la actividad sarracena en la península itálica y las luchas partidarias entre las familias aristocráticas de Roma. Los condes de Túsculo aprovecharon la coyuntura desfavorable para el pontificado y utilizaron su poder para entrometerse continuamente en las elecciones papales, lo que dio comienzo a un periodo de decadencia para la sede apostólica, que el autor define como el Siglo de Hierro del pontificado medieval. Finalmente, el choque contradictorio entre la pretensión de soberanía de los papas y el proyecto político imperial se vio, una vez más, reavivado durante esta época con la llegada de la dinastía otónida al gobierno del Sacro Imperio Romano Germánico.

La tercera parte abarca la segunda mitad del siglo XI hasta finales del siglo XIII, y es tal vez la fase más significativa, ya que en este momento se consolidó un modelo de monarquía pontificia de carácter teocrático, que reclamó cada vez más su independencia respecto al poder laico. Los pontífices que gobernaron la Iglesia durante estos dos siglos supieron aplicar reformas orientadas a sanear las costumbres del clero, dotar a la Iglesia de sólidas bases jurídicas y administrativas y, sobre todo, fortalecer las doctrinas del primado apostólico en materia espiritual y política. Para de Ayala, los orígenes del movimiento reformista pueden remontarse al papa León IX y sus consejeros, los cuales estaban relacionados con la corte imperial y el monacato lorenés de Gorze, en donde se veía la posibilidad de llevar a cabo una reforma bajo la tutela política secular, siempre y cuando se mantuviera el equilibrio de poderes. En este sentido, el autor explica que los límites impuestos por este planeamiento al concepto de libertas Ecclesiae provocaron que el reformismo buscara desvincularse paulatinamente del ámbito donde se había generado. Una coyuntura favorable para el papado, la minoría de edad del emperador Enrique IV, permitió realizar este alejamiento y, con la llegada del papa Gregorio VII, el proceso reformista se intensificó. 
En esta parte del libro también se explica cómo los papas de esta época también incrementaron su liderazgo militar comandando ejércitos y contrayendo juramentos de vasallaje. De Ayala sostiene, en ese sentido, que esto permitió la formación del concepto de guerra santa, el cual tomó mayor significado con la predicación de la primera cruzada por Urbano II durante el concilio de Clermont en 1095. En esa ocasión, el pontífice se presentó como único protector de la fe católica y por encima de los poderes laicos, reforzando así las pretensiones universalistas de la Santa Sede. Los papas utilizaron el llamamiento a la cruzada como una herramienta política para conseguir sus objetivos, dirigiéndola, en muchos casos, contra los mismos cristianos acusados de herejía o heterodoxia. Efectivamente, otra de las preocupaciones de los pontífices de esta época fue resaltar la autoridad del primado apostólico en materia dogmática, celebrando importantes concilios - por ejemplo, el de Letrán IV-y monopolizando la lucha contra la herejía mediante herramientas como la Inquisición pontificia. La teocracia de la monarquía papal llegó a su cenit con el gobierno de Inocencio III, el cual supo autoproclamarse como único vicario de Cristo en la tierra. Es evidente también cómo en este periodo el universalismo papal chocó abiertamente con la política imperial de los Hohenstaufen, lo que dio lugar a importantes disputas por el poder sobre la Cristiandad. Sin embargo, para el autor, a finales del siglo XIII este modelo teocrático comienza su agotamiento, sobre todo, a raíz de las intromisiones de la santa Sede en los conflictos franco-aragoneses por el control del sur de Italia estallados tras las Vísperas Sicilianas en 1282.

La cuarta parte del libro analiza los sucesos del siglo XIV. Esta fase del pontificado medieval es definida como un periodo de crisis y cuestionamientos a la monarquía papal. Los papas de esta época se enfrentaron con monarquías fuertes, que intentaron finalizar con las intromisiones de todo tipo en los asuntos de sus reinos, incluyendo el gobierno de la Iglesia. En este contexto, de Ayala sitúa el desarrollo de los conflictos entre el rey Felipe IV de Francia y el papa Bonifacio VIII, que ocasiona luego el establecimiento de la corte pontificia en Aviñón bajo la tutela francesa. Desde su nueva ubicación, los pontífices intentaron responder a las dificultades económicas de la santa Sede creando un formidable sistema de recaudación. El papa Juan XXII será el principal ideólogo de esta política económica destinada a recuperar el ejercicio de la plenitudo potestatis y financiar las guerras en Italia. Una vez pacificados los Estados pontificios, se intentó un nuevo traslado de la corte papal a Roma que provocó, en 1378, un profundo cisma de la Iglesia, producto del cual, la doctrina del primado y, sobre todo, la autoridad del papa fue cuestionadas seriamente. A causa de esta situación, la necesidad de reunificar la Iglesia, sumado al fracaso de las vías conventuales, dio lugar al nacimiento de las teorías conciliares que buscaron poner límite al poder papal y proponer un nuevo equilibrio en la forma de gobierno de la Iglesia. Sin embargo, de Ayala plantea que los pontífices no renunciaron a su autoridad tan fácilmente.

La quinta parte del libro abarca el siglo XV y corresponde a la última fase del pontificado medieval. Para de Ayala, este es un momento en el que el papado atravesó 
un progresivo rearme frente a las posturas conciliaristas y reclamó el ejercicio de su plenitudo potestatis. De todas maneras, para el autor, la dimensión universal del poder papal se encontraba seriamente cuestionada, no solo por las monarquías temporales, sino también por algunos sectores de la Iglesia y, a partir del gobierno de Inocencio VIII, la sede apostólica entró en un punto de no retorno, puesto que el sistema político religioso entró en crisis dejando de esta manera "un campo abonado para la Reforma".

A pesar de la complejidad de los problemas tratados, el libro ofrece una lectura amena y comprensible para un público en general. En este sentido, para profundizar en la comprensión de los temas, el autor incluyó un mapa ilustrativo de la formación de los Estados Pontificios, una selección documental de ocho textos, un listado cronológico de las sucesiones pontificias, desde su origen hasta el siglo XVI, y una selección bibliográfica orientativa. A pesar de que de Ayala adhiere a ciertos planteamientos estatistas muy difundidos entre los medievalistas y fuertemente criticados por la historiografía reciente, ${ }^{1}$ este libro es un gran trabajo actualizado de síntesis en lengua española, que reúne numerosos puntos de vistas poco tradicionales respecto a los estudios del pontificado medieval y por este motivo está destinado a convertirse en un material de consulta obligatorio para todos aquellos interesados al tema.

\title{
Referencias bibliográficas
}

Asenjo-González, M. y Zorzi, A. (2015). Conflicto y discordia en ciudades bajomedievales. Italia y reinos hispánicos. Hispania, 75 (250), 323-330.

Correa, M. P. (2016). La integración de la nobleza en los oficios de la Corte de Fernando IV de Castilla (1295-1312). Revista chilena de estudios medievales, 9, 63-77.

Lazzarini, I. (2010). Amicizia e potere. Reti politiche e sociali nell'Italia medievale. Milano: Bruno Mondadori.

Haemers, J. (2009). Factionalism and State Power in the Flemish Revolt (1482-1492). Journal of Social History, 42, 1009-1039.

\author{
Pietro Giovanni Zampar \\ Universidad Nacional de Salta \\ giovannizampar@gmail.com
}

\footnotetext{
${ }^{1}$ El medievalista francés, Jean Philippe Genet, actualmente coordina un amplio grupo de investigación interesado en el estudio de los orígenes bajomedievales del estado moderno. Sin embargo, recientemente el paradigma estatalista fue criticado por una historiografía que explica la organización política medieval en base a la articulación de los vínculos personales. Véase: Asenjo-González y Zorzi (2015); Correa (2016); Lazzarini (2010); Haemers (2009).
} 